evoked epilepsy, ${ }^{3}$ especially in India, and childhood epilepsy may be produced by undressing before being bathed. ${ }^{4}$ Swimming and bathing are known to trigger transient global amnesia. Light shimmering on rippled water may be a factor, particularly in younger patients. ${ }^{5}$ Startle effects during horseplay when swimming is another possibility. ${ }^{5}$ True water-immersion epilepsy ("bath epilepsy") ${ }^{4}$ is rare. Infantile febrile convulsions are a threat, especially in view of the common but mistaken parental practice of putting a child who has had a convulsion into a hot bath (cases 1 and 2 ; see table).

In this study the incidence of epilepsy-induced immersions was $5.4 \%$ (epilepsy-induced fatal immersions $3.6 \%$ ). In Maryland $3.4 \%$ of all drownings are due to epileptiform seizures, and in Hawaii $4.6 \%$ of sea drowned victims are epileptics. No epilepsy-induced deaths were reported during swimming in a survey of death during sport in South Africa.

Epileptic children should be encouraged to engage in recreation and sport. Competitive swimming, however, may produce somatic stress to the point of exhaustion, which is a trigger for stress epilepsy. Epileptics should never swim or bathe alone (as opposed to showering), and special risks apply to retarded children with epilepsy. With effective supervision, however, epileptic children may swim with confidence.

I thank Dr B Appleton, of the Royal Children's Hospital, Brisbane, and Dr Ian Wilkey, of the Laboratory of Microbiology and Pathology, Brisbane, for encouragement and access to cases.

Requests for reprints should be addressed to: Dr J H Pearn, Department of Child Health, Royal Children's Hospital, Herston, Brisbane, Australia 4029.

${ }^{1}$ Pearn, J H , Nixon, J, and Wilkey, I, Medical fournal of Australia, 1976, 2, 942.

2 Worster-Drought, C, Lancet, 1970, 2, 876

${ }^{3}$ Mani, K S, et al, Neurology (Bombay), 1974, 20, 237.

4 Keipart, J A, Medical fournal of Australia, 1972, 2, 1124.

${ }^{5}$ Mellor, D H, Developmental Medicine and Child Neurology, 1970, 12, 800.

(Accepted 15 February 1977)

University of Queensland, Queensland, Australia

JOHN H PEARN, MD, FRACP, reader in child health

\section{Bacterial septicaemia with multiple organisms complicating influenzal pneumonia}

We report a case of fatal bacterial septicaemia secondary to influenza B pneumonia, in which six bacterial species were isolated on two occasions from blood cultures three days after the onset of symptoms. Staphylococcus aureus subsequently became the dominant pathogen. Such a phenomenon has not been previously reported.

\section{Case report}

A 17-year-old schoolgirl was admitted to hospital in February 1976. She had been healthy until two days previously, when she developed a cough, sore throat, slight hoarseness, coryza, and myalgia. The next day she complained of bilateral pleuritic chest pain and vomited several times. She was admitted on the following afternoon after further deterioration. She had a temperature of $39.5^{\circ} \mathrm{C}$, and looked ill and flushed, with a coated tongue, and a sinus tachycardia of $140 /$ minute. Examination of the chest showed bronchial breathing and crepitations in the right midzone and left lower zone. There were no other abnormal physical signs. Chest radiography (figure) showed opacities, suggesting segmental consolidation in the right upper lobe and the left lower lobe, with some patchy changes in the right middle and lower zones. The initial blood count showed a normal haemoglobin concentration of $13.7 \mathrm{~g} / \mathrm{dl}$ and leucopenia of $3.7 \times 10^{9} / 1$ $\left(3700 / \mathrm{mm}^{3}\right) ; 71 \%$ neutrophils, $15 \%$ lymphocytes, $11 \%$ monocytes, and $3 \%$ metamyelocytes. Erythrocyte sedimentation rate (ESR) was $30 \mathrm{~mm}$ in the first hour. A blood film showed a left shift of neutrophils. Blood was cultured and she was started on penicillin 2 megaunits twice daily with probenecid.

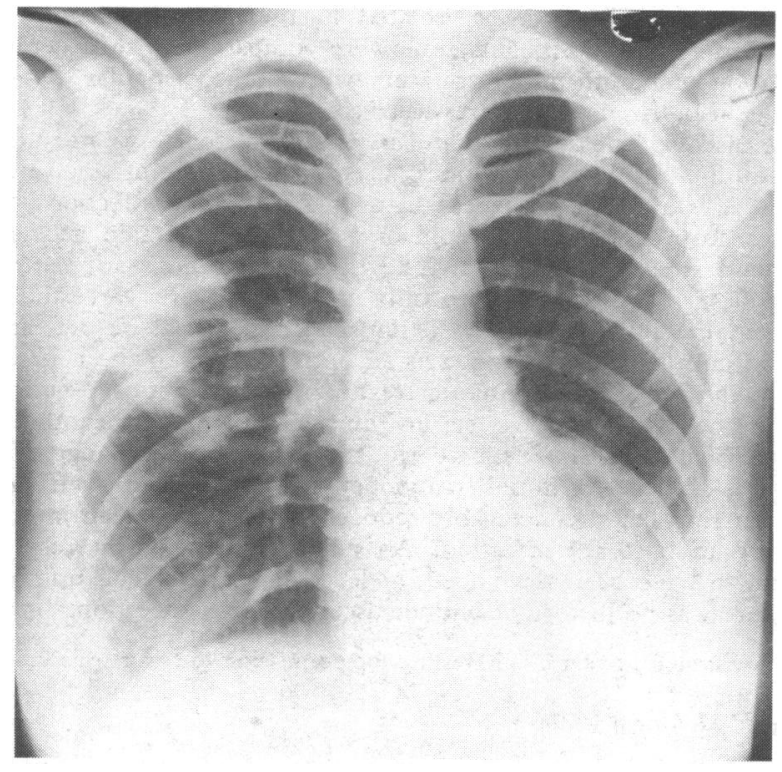

Anteroposterior view of chest taken on portable $x$-ray machine with patient erect. Opacities suggest segmental consolidation in right upper lobe and left lower lobe, with patchy changes in right middle and lower zones.

At midday on the following day ( 22 hours after admission) her condition deteriorated suddenly, with circulatory collapse, arterial hypotension, tachycardia, cyanosis, and continuing fever. Chest radiography showed more extensive opacities in all previously affected areas, and the arterial $\mathrm{Po}_{2}$ was reduced to $4.8 \mathrm{kPa}(36 \mathrm{~mm} \mathrm{Hg})$. Intermittent positive-pressure ventilation was begun and she was given intravenous methylprednisolone $1.5 \mathrm{~g}$ and started on gentamicin and flucloxacillin. The white cell count remained low at $3.6 \times 10^{9} / 1\left(3600 / \mathrm{mm}^{3}\right)$, but two days later had risen to $12.0 \times 10^{9} / 1\left(12000 / \mathrm{mm}^{3}\right)$ with $87 \%$ neutrophils and an ESR of $102 \mathrm{~mm}$ in the first hour. Aspiration of tracheal secretions produced scanty but heavily blood-stained sputum. After ventilation and steroid treatment her circulatory state and $\mathrm{Po}_{2}$ improved slightly, but she remained hypotensive and became oliguric. Over the next few days she developed purpura and conjunctival haemorrhages. Coagulation studies suggested an intravascular coagulopathy, with prolonged prothrombin time, thrombocytopenia, and increased fibrin degradation products. A low-dose heparin regimen was started together with whole-blood and platelet transfusions. After further deterioration over the next few days with falling arterial blood pressure and a rising blood urea concentration she went into ventricular fibrillation, and after rescuscitation developed signs of a brainstem cerebrovascular accident with constricted pupils and bilateral extensor plantar responses. Shortly afterwards she died in asystole, six days after admission. The principal necropsy findings included extensive laryngeal and tracheal ulceration with exudate; bilateral lung consolidation with abscess formation and areas of segmental infarction; petechial brain haemorrhages involving the meninges, cerebral hemispheres, and pons; and acute tubular necrosis. There was also a thrombus on the mitral valve, and two recent splenic infarcts.

Bacteriology and virology-Two sets of blood samples were cultured before starting treatment. Both of these yielded a growth of Haemophilus influenzae, Neisseria catarrhalis, Staphylococcus albus, two species of $\alpha$-haemolytic streptococci, and Staphylococcus aureus phage type 29/52/52a/ 80. This organism was subsequently cultured from the sputum and from necropsy material from the mitral valve, trachea, and both lungs. A throat swab was taken three days after admission and inocculated into cell lines MRC 5 and monkey kidney. Influenza $B$ virus was identified in these cells. Viral agglutinin titres on the same day showed nothing abnormal. The influenza $B$ titre was $1 / 10$ but had risen to $1 / 40$ in a specimen of heart blood collected at necropsy.

\section{Comment}

The clinical course of events described here is not especially unusual. It shows one of the gravest sequelae of influenza in a young person - the syndrome of viral pneumonia with secondary fulminating bacterial infection and septicaemia-in this case complicated by circulatory collapse, acute tubular necrosis, and disseminated intravascular coagulation. The infecting organism is usually Staphylococcus aureus and was, in this case, ultimately the predominant pathogen. The initial yield of multiple organisms from blood cultures is a most unusual feature, however, and we cannot find written reference to it 
elsewhere. "Mixed" cultures are normally regarded as evidence of contamination. The bacteria isolated in these cultures could not have been skin contaminants, but were compatible with a genuine population of mouth and respiratory tract flora, particularly as the findings in both sets of cultures were consistent.

The discovery of denuding and ulceration of the respiratory tract epithelium at necropsy provides an obvious mode of entry, and since this is a well-established feature of influenzal infections it is perhaps surprising that multiple organisms do not gain access to the blood stream more often. The necropsy findings suggest that the damage in this case was probably unusually severe. Nevertheless, the phenomenon may not be so unusual, and would be detectable if blood cultures were obtained at an optimal stage in the course of such an illness before antibiotic treatment. There was no evidence of immune deficiency, as serum immunoglobulin concentrations were normal, and an adequate (fourfold) rise in viral agglutinin titres was shown. An initial lymphopenia is common in severe viral infections but could conceivably reduce the efficiency of an immune response to bacterial infection. An adequate polymorph response appears to have been developed, at least in terms of cell numbers, and there was no history of undue susceptibility to infection.

We are grateful to $\mathrm{Dr} C \mathrm{M}$ Hesling for permission to report this case.

(Accepted 11 March 1977)

\section{Wythenshawe Hospital, Manchester M23 9LT}

P V BARBER, MB, MRCP, senior registrar in thoracic medicine T N STANBRIDGE, MD, MRCPATH, consultant microbiologist

\section{Myasthenia gravis : acetylcholine-receptor antibody titres after thymectomy}

Antibodies to the nicotinic acetylcholine receptor, recently shown in myasthenia gravis, ${ }^{12}$ may be responsible for the characteristic neuromuscular block. Thymitis and thymomas are common in myasthenia, and thymectomy has long been known to alleviate the disease. It is not known how the thymus is implicated. If it were the source of the antibodies, as suggested by the presence of germinal centres containing B lymphocytes in the thymic medulla, there should be a rapid fall in titre after thymectomy. If, however, thymectomy merely removes the source of an antigen shared with striated muscle (nicotinic acetylcholine receptors are present in thymus tissue) any fall in antibody titre might be considerably delayed. This would also be the case if thymectomy acted via the removal of long-lived $T$ lymphocytes. Furthermore, if the receptor antibody is responsible for the neuromuscular block there should be some correlation between the antibody titre and the clinical improvement after thymectomy. We have tested this hypothesis and report here our results.

\section{Patients, methods, and results}

We studied 21 patients with myasthenia gravis (see table)-14 with thymitis after thymectomy (group 1), three with thymomas after thymectomy (group 2), and four before thymectomy (group 3). Serum antibody titres were measured by competitive immunoprecipitation with human acetylcholine receptor labelled with ${ }^{125} \mathrm{I} \alpha$-bungarotoxin. ${ }^{2}$ Titres exceeding $0.619 \times 10^{-9} \mathrm{~mol} \alpha$-bungarotoxin precipitated $/ 1$ are found only in patients with myasthenia gravis, the mean titre in myasthenia being $54.3 \times 10^{-9}$ $\mathrm{mol} / \mathrm{l}$. The significance of the difference between two means for independent samples was determined by Student's $t$ test.

There were no significant differences in mean antibody titres between group 1 when taken as a whole and groups 2 and 3 (table), possibly because of the small numbers of patients in groups 2 and 3. Patients in group 1 who had improved clinically after thymectomy-that is, with response A, B, or $\mathrm{C}^{3}$-however, had a significantly lower mean antibody titre than group 3 , even when the patient with a thymoma (case 21$)$ was excluded $(P<0.01)$.

In group 1 antibody titres fell with the increasing number of years since thymectomy $(0.1>\mathrm{P}>0.05)$. Of the patients in complete remission (response A), however, only one (case 11) had a titre within the normal range.
Clinical details and antibody titres in the 21 cases of myasthenia gravis

\begin{tabular}{|c|c|c|c|c|c|c|}
\hline $\begin{array}{l}\text { Case } \\
\text { No }\end{array}$ & Sex & $\begin{array}{l}\text { Years since } \\
\text { thymectomy }\end{array}$ & $\begin{array}{l}\text { Years from } \\
\text { onset of } \\
\text { myasthenia } \\
\text { gravis to } \\
\text { thymectomy }\end{array}$ & $\begin{array}{l}\text { Initial grade } \\
\text { of } \\
\text { myasthenia }\end{array}$ & $\begin{array}{l}\text { Response to } \\
\text { thymectomy }\end{array}$ & $\begin{array}{l}\text { Antibody } \\
\text { titre } \\
\times 10^{-9} \mathrm{~mol} / 1\end{array}$ \\
\hline
\end{tabular}

\begin{tabular}{|c|c|c|c|c|c|c|}
\hline & & & & & & \\
\hline $1 *$ & $\mathrm{~F}$ & 1 & 2 & II & $\mathrm{E}$ & $43 \cdot 4$ \\
\hline 2 & $M$ & 2 & 19 & II & $\mathrm{E}$ & 33.5 \\
\hline 3 & $\mathrm{~F}$ & 11 & 1 & II & $\vec{E}$ & 125.0 \\
\hline 4 & $\mathrm{~F}$ & 11 & $3 / 12$ & III & B & 0.895 \\
\hline 5 & $\mathrm{~F}$ & 11 & $2 !$ & III & B & 0.349 \\
\hline 6 & $M$ & 16 & 3 & II & B & $12 \cdot 8$ \\
\hline 7 & $\mathrm{~F}$ & 20 & 7 & II & A & 11.4 \\
\hline 8 & $\mathrm{~F}$ & 21 & 1 & II & $\mathrm{A}^{\prime}$ & 1.39 \\
\hline 9 & $\mathrm{~F}$ & 27 & 13 & II & B & $13 \cdot 4$ \\
\hline 10 & $\mathrm{~F}$ & 28 & 1 & II & B & $2 \cdot 62$ \\
\hline 11 & $\mathrm{~F}$ & 28 & $3 / 12$ & III & A & 0.276 \\
\hline 12 & M & 30 & 36 & $\mathrm{~V}$ & C & 0.273 \\
\hline 13 & $\mathrm{~F}$ & 31 & 2 & II & A & 2.08 \\
\hline 14 & $M$ & 34 & $9 / 12$ & III & A & 0.641 \\
\hline & & & & & & \\
\hline $15 *$ & $M$ & 10 & 3 & II & $\mathrm{E}$ & $52 \cdot 8$ \\
\hline $16^{*}$ & $\mathrm{~F}$ & 2 & $2 !$ & III & B & 42.5 \\
\hline $17^{*}$ & M & 1 & 1 & II & $\mathrm{E}$ & 28.9 \\
\hline & & & & & & \\
\hline 18 & & & & II & & 2.08 \\
\hline 19 & $\mathrm{~F}$ & & & I & & 68.6 \\
\hline 20 & $\mathrm{~F}$ & & & III & & $21 \cdot 6$ \\
\hline $21+$ & $M$ & & & II & & $50 \cdot 8$ \\
\hline
\end{tabular}

*Patients receiving steroids or steroids and immunosuppressant drugs at time of study. + Thymoma found at subsequent operation.

: Osserman's ${ }^{3}$ classification, as follows: A complete remission but subsequent exacerOsserman's classifeation, as follows: A, complete remission but subsequent exacer-
bation; A, complete remission; B, marked improvement with decreased anticholinesterase medication; C, marked improvement without decreased anticholinesterase medication; D, no improvement but decreased anticholinesterase medication; $E$, no change.

Two other patients with low titres (cases 5 and 12) were still taking small doses of pyridostigmine. Patients in group 1 who had had an abrupt, severe onset of generalised myasthenia $\left(\right.$ grade $\mathrm{III}^{3}$ ) all had normal or low titres. This was not explicable by earlier operation, as there was no correlation between time to operation and subsequent antibody titre.

\section{Comment}

These results suggest that clinical improvement is associated with a progressive decrease in anti-receptor antibody titre over several years. Hence a major source of antibody is probably not removed by thymectomy, as in that case the titre would fall more quickly. Thymectomy may remove an antigenic stimulus or cause a gradual decrease in $T$ lymphocytes necessary for antibody formation by $B$ lymphocytes. We have confirmed a reported fall ${ }^{4}$ in the number of E-rosetting cells after thymectomy (unpublished observation). The association between clinical improvement and the fall in antibody titre after thymectomy is indirect evidence that anti-receptor antibodies have a pathogenic role in myasthenia gravis. A fall in antibody titre has also been reported after remissions induced by corticosteroids. ${ }^{5}$ We are now performing long-term studies before and after thymectomy to further investigate this problem.

Our thanks are due to Dr Vanda Lennon, who made possible the antireceptor antibody assays, and to $\mathrm{Mr} M \mathrm{~J}$ Lange and $\mathrm{Dr} M$ Sarner, whose patients we have included. The serum antibody titres were measured by Dr J Lindstrom at the Salk Institute, San Diego.

Almon, R R, Andrew, C G, and Appel, S H, Science, 1974, 186, 55.

2 Lindstrom, J M, et al, Neurology (Minneapolis), 1976, 26, 1054.

3 Osserman, K E, in Myasthenia Gravis. New York, Grune and Stratton, 1958.

${ }^{4}$ Koziner, B, Bloch, K J, and Perlo, V P, Annals of the New York Academy of Sciences, 1976, 274, 411.

${ }^{5}$ Lindstrom, J M, et al, Annals of the New York Academy of Sciences, 1976, 274, 254 .

(Accepted 9 February 1977)

Royal Free Hospital, London NW3 2QG

G K SCADDING, MB, MRCP, Abbott research fellow

H C THOMAS, PHD, MRCP, lecturer in medicine

C W H HAVARD, DM, FRCP, consultant physician and endocrinologist 